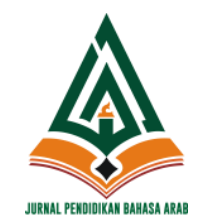

\author{
Alibbaa': Jurnal Pendidikan Bahasa Arab \\ Vol. 2 No. 1, January 2021 \\ P-ISSN: 2721-1606 | E-ISSN: 2716-4985 \\ doi: https://doi.org/10.19105/alb.v2i1.4130
}

\title{
Makna Referensial Pada Komik Bahasa Arab Nawâdhîr Jûhâ Li al-Athfâl
}

\author{
Reni Lailina Hidayah \\ State Islamic University of Maulana Malik Ibrabim Malang \\ Corresponding Email: Lailinab1@,gmail.com
}

\begin{abstract}
This qualitative descriptive study aims to describe the referential meaning contained in the Arabic comic Nawadhir Juha li al-Athfal, and to explain the referential meaning in the Arabic comic Nawadhir Juha li al-Athfal. The data in this study are in the form of writings that can be extracted from the referential meaning of the Arabic comic Nawadhir Juha li al-Athfal. The data collected in this study used the reading and note technique method with the data analysis technique using the intralingual and extra lingual matching methods. The matching method is followed by the basic technique of Sorting Determining Elements. The theory used is the theory of meaning Ferdinand De Saussure. The results of the analysis in this study are that there are eighteen referential meanings in the comic Nawadhir Juha li al-Athfal.
\end{abstract}

Keywords: semantics, referential meaning, Arabic comics, Nawadhir Juba li al-Athfal. 


\section{Pendahuluan}

Kajian makna terus mengalami perkembangan. Hal ini sejalan dengan bahasa yang bersifat dinamis sehingga memungkinkan untuk mengalami perubahan sewaktu-waktu. Munculnya kosa kata baru seperti mager, pansos, daring merupakan salah satu bukti dari kedinamisan bahasa. Bahasa bergerak dan berkembang sesuai dengan pergerakan dan perkembangan zaman. Sifat kebaruan tersebut membuat bahasa menarik untuk terus dikaji. Bahasa yang berfungsi sebagai alat untuk berkomunikasi tentu tak terlepas dari kajian makna. Menurut De Saussure setiap tanda lingusitik atau tanda bahasa terdiri dari dua komponen, yaitu siginifian (yang mengartikan) dan signifie (yang diartikan) yang wujudnya berupa pengertian atau konsep ${ }^{1}$.

Makna sendiri terdiri dari beberapa jenis, hal itu disebabkan oleh fungsi bahasa itu sendiri. Bahasa dipakai dalam berbagai kegiatan dan kebutuhan di masyarakat ${ }^{2}$. Dalam bahasa Arab, satu kata bisa memiliki beberapa makna, bahkan kata tertentu akan memiliki makna yang berbeda jika memiliki pasangan kata yang berbeda. ${ }^{3}$ Diantara jenis makna bahasa adalah makna leksikal (menurut Aristoteles sama dengan makna otonom $)^{4}$ dan gramatikal, makna denotatif dan konotatif, makna konseptual dan asosiatif, makna referensial dan nonreferensial. Makna yang terbentuk dengan menghubungkan tanda bahasa (tuturan) dengan konteks situasi tutur itu disebut dengan makna pragmatik. ${ }^{5}$ Makna yang terbentuk karena tanda bahasa (tuturan) dihubungkan dengan konteks tuturannya disebut maksud ${ }^{6}$.

Adapun makna referensial adalah suatu leksem atau kata yang memiliki referensi atau acuan dalam dunia nyata. Seperti contoh, kata buku, kita dapat melihat bentuk buku itu dalam dunia nyata. Beda halnya dengan kata dan, karena, dan atau yang tidak memiliki acuan

\footnotetext{
${ }^{1}$ Abdul Chaer, Linguistik Umum (Jakarta: Rineka Cipta, 2007), 286.

${ }^{2}$ Chaer, 289.

${ }^{3}$ Ade Destry Deviyana, 'Ilm ad-dalalah: 'Alaqatul Ma'na fi al-Lughah al-Arabiyah wa al-Lughah Al-Injiliziyah wa al-Lughah al-Indunisiyah', Al-Ta'rib : Jurnal Ilmiah Program Studi Pendidikan Bahasa Arab IAIN Palangka Raya 4, no. 1 (1 June 2016), https://doi.org/10.23971/altarib.v4i1.557.

${ }^{4}$ Keith Allan, Natural Language Semantics (Oxford, UK; Malden, Mass: Blackwell, 2001).

${ }^{5}$ Geoffrey N Leech and M. D. D Oka, Prinsip-prinsip pragmatik (Jakarta: Universitas Indonesia, 1993).

${ }^{6}$ Stephen C. Levinson, Pragmatics, Cambridge Textbooks in Linguistics (Cambridge [Cambridgeshire]; New York: Cambridge University Press, 1983), 1-47.
} 
dalam dunia nyata. Kata yang tidak memiliki acuan dalam dunia disebut dengan makna non referensial.

Sebagai salah satu alat untuk menyampaikan informasi, bahasa memiliki berbagai macam media. Media merupakan alat penyampai informasi. Seiring perkembangan zaman, ada banyak jenis media, seperti media cetak, tulis, dan media elektronik. Melalui media, informasi bisa lebih mudah tersampaikan bahkan kepada semua masyarakat sekitar ${ }^{7}$.

Diantara media penyampai informasi adalah komik. Komik merupakan Salah satu media tulis dalam menyampaikan informasi. Selain sebagai penyampai informasi, komik juga berfungsi sebagai hiburan. Komik dalam pengertian umum adalah rangkaian cerita bergambar dalam surat kabar, majalah atau buku yang pada umumnya mudah dicerna dan bersifat lucu ${ }^{8}$. Melalui media komik informasi dapat dikemas sedemikian rupa, sehingga terlihat lebih menarik dan mudah dipahami.

Komik Nawadhir Juha li al-Athfal ini merupakan tulisan Syawqi hasan. Komik ini diterbitkan oleh al-Muassasah al-'Arabiyyah al-Haditsah, Kairo. Komik ini menceritakan tentang kisah-kisah Juha. Cerita ini digolongkan ke dalam cerita anekdot (humor). Juha merupakan salah satu cerita yang paling masyhur di sekitar Timur Tengah dan Afrika Utara ${ }^{9}$. Juha telah menjadi inspirasi banyak karya yang merupakan refleksi dari kualitas, tokoh yang kompleks, dan pandai mengolah kata. Banyak dari kisah-kisahnya yang konyol, meski demikian kisah-kisahnya berbobot. Banyak kisahnya pula yang menjadi media dari kritik sosial. la juga cukup arif untuk memberikan wejangan, nasihat, mengejek kebodohan, kata-kata bijak, protes, ketidak becusan/ketidak adilan, dan bahkan bisa menghibur hati yang sedang tidak baik-baik saja. Komik juga dapat digunakan guru sebagai

\footnotetext{
7 Tivany Inggar Priatmie and Atiqa Sabardila, 'Makna Referensial Pada Kritikan Di Situs Ngomikmaksa Dan Relevansinya Sebagai Bahan Ajar Di SMA', Jurnal Penelitian Humaniora 17 (2016): 110-22.

${ }^{8}$ Alex Sobur, Semiotika Komunikasi (Bandung: PT Remaja Rosdakarya, 2013), 137.

${ }_{9}^{9}$ Medita Agla Cahyani, 'Penerjemahan Komik Nawadhir Juha Li Al-Athfal' (Jakarta, Universitas Islam Negeri Syarif Hidayatullah, 2018), https://www.academia.edu/35723006/
} 
media pembelajaran yang hemat dan efektif, hal itu karena tampilan dari komik yang menarik bagi anak-anak. ${ }^{10}$

Berkenaan dengan penelitian ini, peneliti menemukan beberapa studi tentang makna referensial. Pertama, penelitian mengenai analisis makna referensial pada rubrik pendidikan dalam surat kabar yang dilakukan oleh Kurniawan dkk. Para peneliti tersebut mengemukakan terdapat 14 kutipan pada rubrik pendidikan yang mengandung makna referensial. Seperti kata kabel dalam rubrik pendidikan tersebut memiliki referen berupa gambar rakitan kabel listrik ${ }^{11}$. Persamaan penelitian tersebut dengan penelitian ini adalah sama-sama mengkaji makna referensial. Perbedaannya adalah kajian makna referensial dalam penelitian tersebut adalah berupa rubrik pendidikan dalam surat kabar sementara dalam penelitian ini berupa komik berbahasa Arab.

Kedua, kajian mendalam yang dilakukan oleh Priatmie dan Sabardila mengenai makna referensial pada kritikan di situs ngomikmaksa dan relevansinya sebagai bahan ajar menemukan hasil penelitian bahwa makna referensial dalam kritikan di situs Ngomikmaksa berupa wujud acuan, yaitu iconic sinsign, ikon argumentasi, iconic legsign, rhematic indexical sinsign, rhematic indexical legsign, dicent indexial legsign, rhematic symbol, dicent symbol, dan simbol tanda baca. Persamaan penelitian tersebut dengan penelitian ini adalah sama-sama mengkaji makna referensial. Perbedaannya adalah kajian makna referensial dalam penelitian tersebut adalah berupa karikatur sedangkan dalam penelitian ini berupa komik berbahasa $\mathrm{Arab}^{12}$.

Ketiga, studi mengenai makna referensial pada istilah pendidikan dalam kolom wacana pendidikan surat kabar harian solopos yang dilakukan oleh Cahyo menemukan hasil penelitian yaitu wujud makna referensial pada istilah pendidikan pada kolom wacana surat kabar harian Solopos edisi Januari-februari 2014 terdiri dari makna referensial pada istilah pendidikan nama profesi berupa kata dan frasa,

10 Sutarjo Sutarjo, 'Istikhdam Wasilah Ar-Rusum al-Hajaliyah Fi Maharah alQira'ah', النابغة/Volume 18 No. 2 (2016): 221-37.

11 Reski Kurniawan, Sumiharti Sumiharti, and Firman Tara, 'Analisis Makna Referensial Pada Rubrik Pendidikan Dalam Surat Kabar Jambi Ekspres Edisi Bulan Maret 2017', Aksara: Jurnal Ilmiah Pendidikan Bahasa Dan Sastra Indonesia Vol. 2 No. 1, 2018: 192-200.

12 Priatmie and Sabardila, 'Makna Referensial Pada Kritikan Di Situs Ngomikmaksa Dan Relevansinya Sebagai Bahan Ajar Di SMA'. 
makna referensial pada istilah pendidikan nama jabatan berupa kata, frasa, singkatan, dan akronim, makna referensial pada istilah pendidikan nama kegiatan berupa kata, singkatan, dan akronim, makna referensial pada istilah pendidikan nama instansi berupa kata, frasa, singkatan, dan akronim. Persamaan penelitian Cahyo dengan penelitian ini adalah sama-sama mengkaji makna referensial. Perbedaannya adalah pada obyek penelitian. Cahyo berupa wacana dalam kolom surat kabar sementara penelitian ini pada komik bahasa Arab $^{13}$.

Selanjutnya, komik Sebagai salah satu media, memiliki daya pikat tersendiri bagi pembacanya. Suatu cerita yang dikemas dengan gambar tentu akan lebih menarik untuk dibaca. Kendati demikian, tidak banyak orang yang melirik komik berbahasa Arab untuk dikaji. Penelitian ini berangkat dari minimnya kajian mengenai komik bahasa Arab. Fokus permasalahan dalam penelitian ini adalah mengkaji makna dan jumlah referensial pada komik bahasa Arab Nawadhir Juha li alAthfal. Penelitian ini bertujuan untuk mendeskripsikan serta menganalisis makna referensial pada komik bahasa Arab Nawadhir Juha li al-Athfal.

\section{Metode Penelitian}

Penelitian ini merupakan penelitian deskriptif kualitatif yang bertujuan untuk mengeksplor, memahami, serta menganalisis makna referensial yang terdapat dalam komik bahasa Arab Nawadhir Juha li al-Athfal. ${ }^{14}$ Sugiyono mengemukakan bahwa penelitian deskriptif digunakan untuk meneliti kondisi obyek yang alamiah yang tidak dimanipulasi oleh peneliti. ${ }^{15}$ Wiersma juga menyampaikan bahwasanya penelitian ini memiliki sifat dasar yaitu analisis deskriptif. ${ }^{16}$ Dengan demikian fokus pada penelitian ini adalah menggambarkan secara analitis dan bersifat deskriptif mengenai makna referensial yang terkandung dalam komik berbahasa Arab Nawadhir Juha li al-Athfal

Data merupakan fenomena lingual yang bersifat khusus dan mengandung serta berkaitan langsung dengan fokus masalah yang

\footnotetext{
${ }^{13}$ Nur Cahyo, 'Makna Referensial Pada Istilah Pendidikan Dalam Kolom Wacana Pendidikan Surat Kabar Harian Solopos Edisi Januari-Februari 2014', 2014.

${ }^{14}$ John W. Creswell, Research Design: Qualitative, Quantitative, and Mixed Methods Approaches, 4th ed (Thousand Oaks: SAGE Publications, 2014).

${ }^{15}$ Sugiyono Sugiyono, Metode Penelitian Pendidikan (Bandung: Alfabeta, 2015), 15.

16 William Wiersma and Stephen G. Jurs, Research Methods in Education: An Introduction., 2009, 12.
} 
dimaksud ${ }^{17}$. Data pada penelitian ini berupa gambar dan tulisan yang dapat digali makna referensialnya pada komik berbahasa Arab Nawadhir Juha li al-Athfal. Metode pengumpulan data yang dipakai adalah teknik baca dan catat. Menghimpun dokumen-dokumen yang berkaitan kemudian dipilih yang sesuai dengan tujuan dan fokus masalah ${ }^{18}$. Dokumentasi dalam penelitian ini berupa komik Bahasa Arab Nawadhir Juha li al-Athfal.

Teknik analisis data dalam penelitian ini adalah metode padan intralingual dan ekstralingual. Pada tahap pertama dalam penelitian ini, metode padan intralingual digunakan untuk menghubung bandingkan kosa kata bahasa Arab yang digunakan dalam komik dengan maknanya dalam bahasa Indonesia. Hal dilakukan karena satu kosakata bahasa Arab memungkinkan untuk memiliki makna lebih dari satu dalam bahasa Indonesia. Pada tahap kedua, metode padan ekstralingual digunakan untuk menghubung bandingkan makna dalam bahasa Indonesia dengan referen yang ada pada komik Bahasa Arab Nawadhir Juha li al-Athfal. Kemudian dilanjutkan dengan teknik dasar pilah unsur penentu (PUP) dengan menggunakan alat berupa daya pilah referensial. Daya pilah ini sesuai dengan jenis-jenis acuan yaitu tanda linguistik, konsep dan referen ${ }^{19}$.

\footnotetext{
17 Sudaryanto Sudaryanto, Metode Dan Aneka Teknik Analis Bahasa (Yogyakarta: Duta Wacana University Press, 2015), 6.

${ }^{18}$ Nana Syaodih Sukmadinata, Metode Penelitian Pendidikan (Bandung: PT Remaja Rosdakarya, 2009), 222.

19 Mahsun Mahsun, Metode Penelitian Bahasa Tahapan Strategi, Metode, Dan Tekniknya (Jakarta: PT Raja Grafindo Persada, n.d.).
} 


\section{Paparan Data dan Hasil Penelitian \\ Makna Referensial}

Telah banyak ahli yang mengemukakan mengenai teori makna. Makna tanda bahasa dapat dipahami dari segi asal makna tanda bahasa dan sifat hubungan antara simbol dan acuannya. ${ }^{20}$ Lyons mempunyai pendapat bahwa tidak ada hubungan yang sistematis atau berarti antara simbol dan acuannya. Hubungan antara simbol dan tanda bahasa bersifat mana suka atau arbitrer $^{21}$. Kemudian Pierce membagi jenis tanda menjadi tiga, yaitu ikon

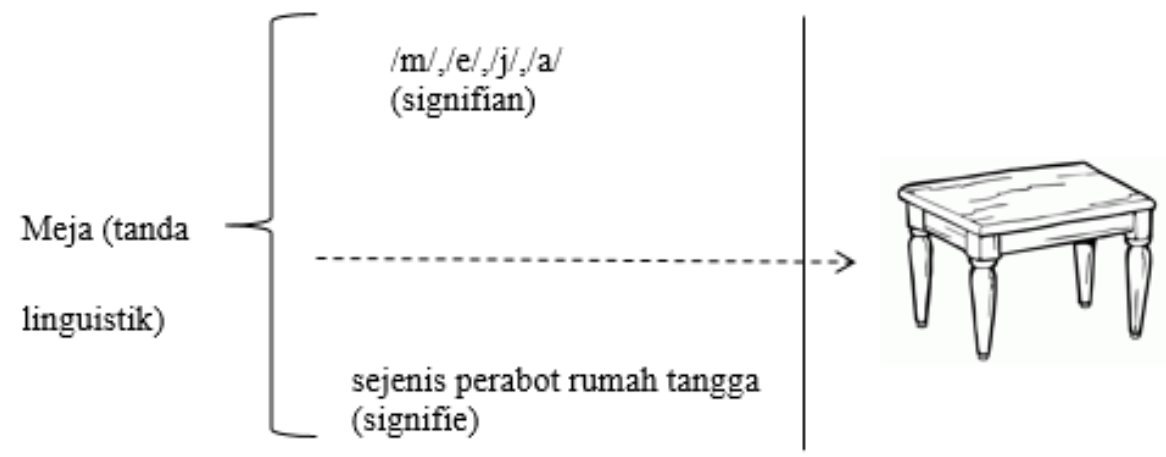

(icon), indeks (index), dan simbol (symbol). ${ }^{22}$ Namun, fokus kajian peneliti adalah teori De Saussure yang menyatakan setiap tanda linguistik atau tanda bahasa terdiri dari dua komponen, yaitu komponen yang mengartikan (signifian) yang wujudnya berupa runtunan bunyi, dan yang diartikan (signifie) yang wujudnya berupa pengertian atau konsep. Seperti tanda linguistik berupa (ditampilkan dalam bentuk ortografis) $\langle$ meja $>$, terdiri dari komponen signifian, yakni berupa runtunan fonem $/ \mathrm{m} / / \mathrm{e} /, / \mathrm{j} / / \mathrm{a} /$; dan komponen signifienya berupa konsep atau makna sejenis perabot kantor atau rumah tangga. Tanda linguistik ini yang berupa runtunan fonem dan konsep yang miliki runtunan fonem itu mengacu pada sebuah referen yang berada di luar bahasa, yaitu "sebuah meja". Kalau dibagankan menjadi sebagai berikut:

20 John Lyons, Semantics (Cambridge; New York: Cambridge University Press, 1977).

21 John Lyons, Linguistic Semantics: An Introduction (Cambridge; New York: Cambridge University Press, 1995).

${ }^{22}$ Winfried Nöth, Handbook of Semiotics (Indiana University Press, 1995), 45. 
Bagan tersebut oleh Ricard dan Orgent ditampilkan dalam sebuah bentuk segitiga yang disebut segitiga makna, atau segitiga Richard dan

b) konsep: sejenis perabot rumah
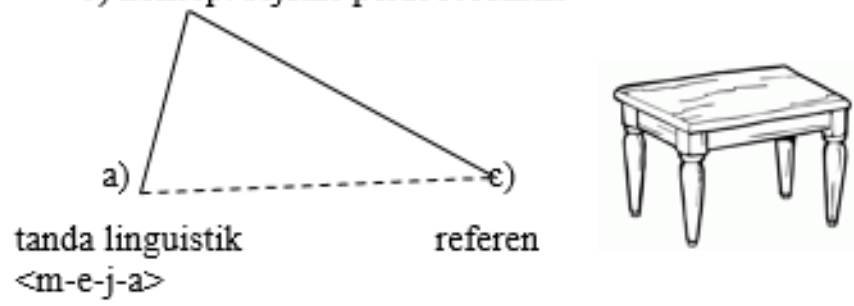

$\operatorname{Ogdent}^{23}$

Komik Nawadhir Juha li al-Athfal ini merupakan komik berbahasa Arab yang diterbitkan oleh al-Muassasah al-'Arabiyyah al-Haditsah, Kairo. Tokoh utama dalam komik ini adalah Juha. Juha digambarkan sebagai tokoh yang kompleks, dan pandai mengolah kata. Banyak dari kisah-kisahnya yang konyol. Dia juga cukup arif untuk memberikan wejangan, nasihat, mengejek kebodohan, kata-kata bijak, protes, ketidak becusan/ketidak adilan. Komik ini terdiri dari 20 judul. Namun peneliti hanya mengambil satu tema yaitu ثيابي

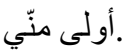

\begin{tabular}{|c|c|}
\hline Komik Nawadhir Juha li al-Athfal & Analisis Makna Referensial \\
\hline 3 & $\begin{array}{l}\text { Judul Komik : ثيابي أولى مني } \\
\text { Tanda : ثياب } \\
\text { Konsep : barang yang dipakai } \\
\text { (baju, celana dan sebagainya) } \\
\text { Referen : gambar nomor 1, } 2 \text { dan } 3 \\
\text { Kata ثوب merupakan bentuk dalam } \\
\text { jamak dari kata yang } \\
\text { kamus bahasa Arab memiliki arti } \\
\text { pakaian. Kata jamak berarti } \\
\text { menunjukkan jumlah yang lebih }\end{array}$ \\
\hline
\end{tabular}

23 James McElvenny, 'Ogden and Richards' The Meaning of Meaning and Early Analytic Philosophy', Language Sciences 41 (January 2014): 212-21, https://doi.org/10.1016/j.langsci.2013.10.001. 
ALIBBAA': Jurnal Pendidikan Bahasa Arab, 2 (1), 2021

\begin{tabular}{|c|c|}
\hline & 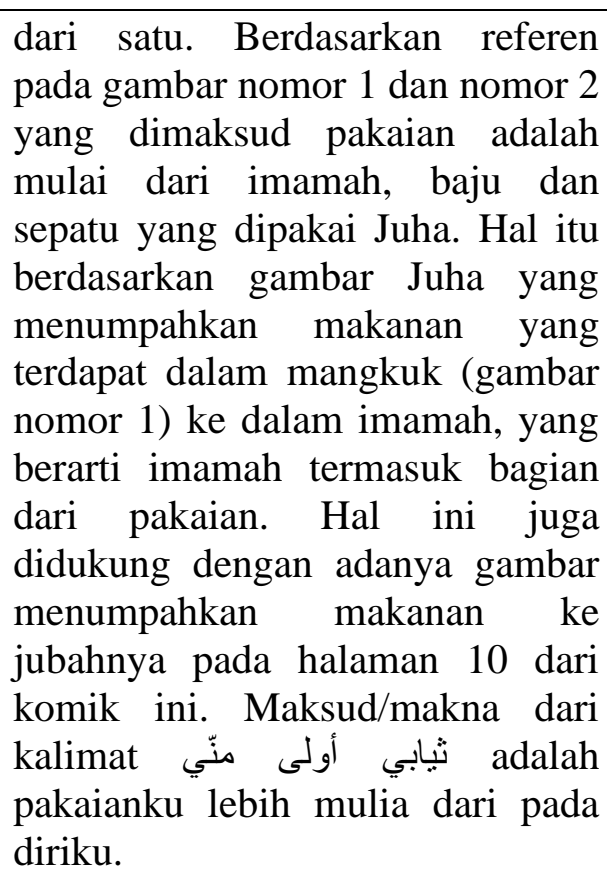 \\
\hline ف & 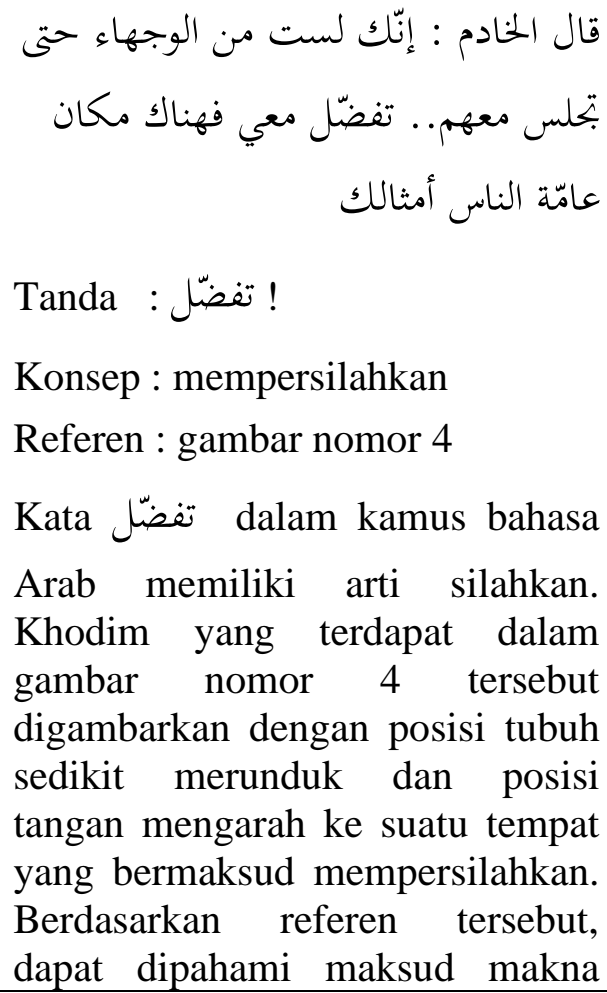 \\
\hline
\end{tabular}




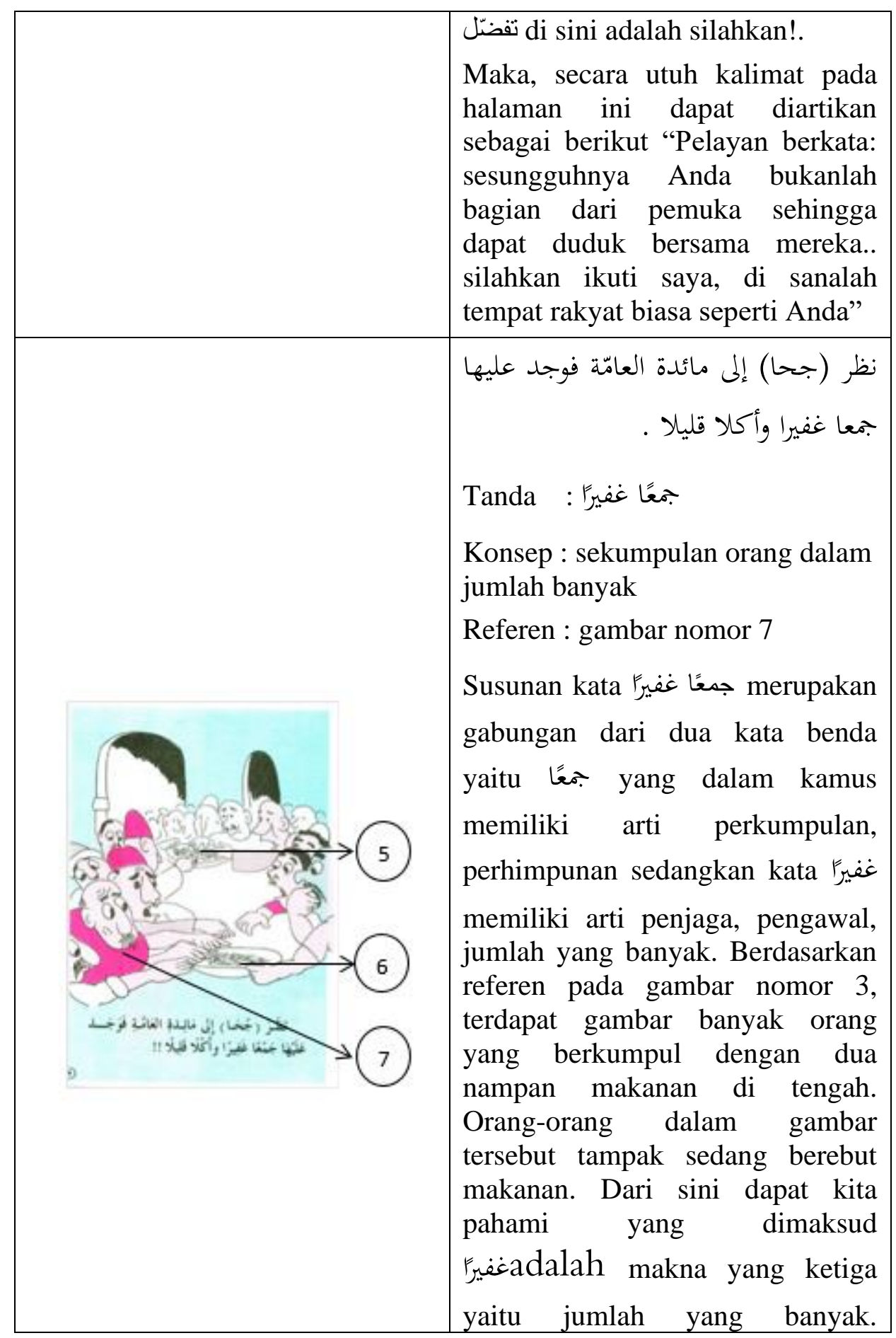


ALIBBAA': Jurnal Pendidikan Bahasa Arab, 2 (1), 2021

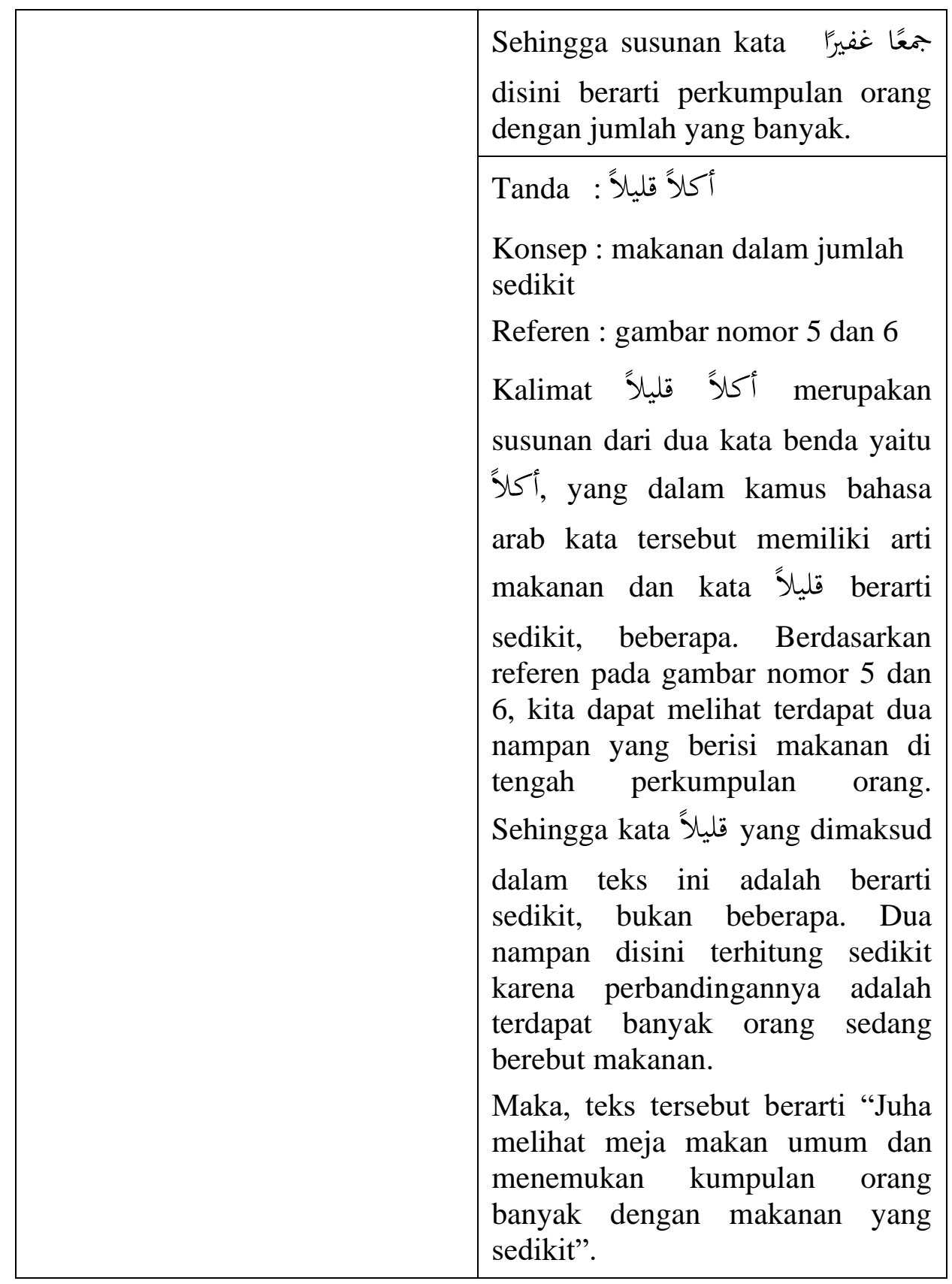




\begin{tabular}{|c|c|}
\hline 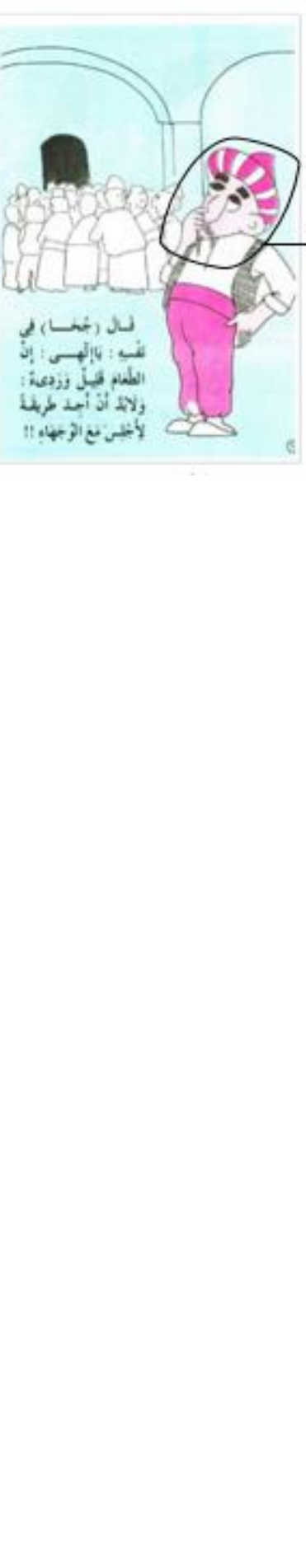 & 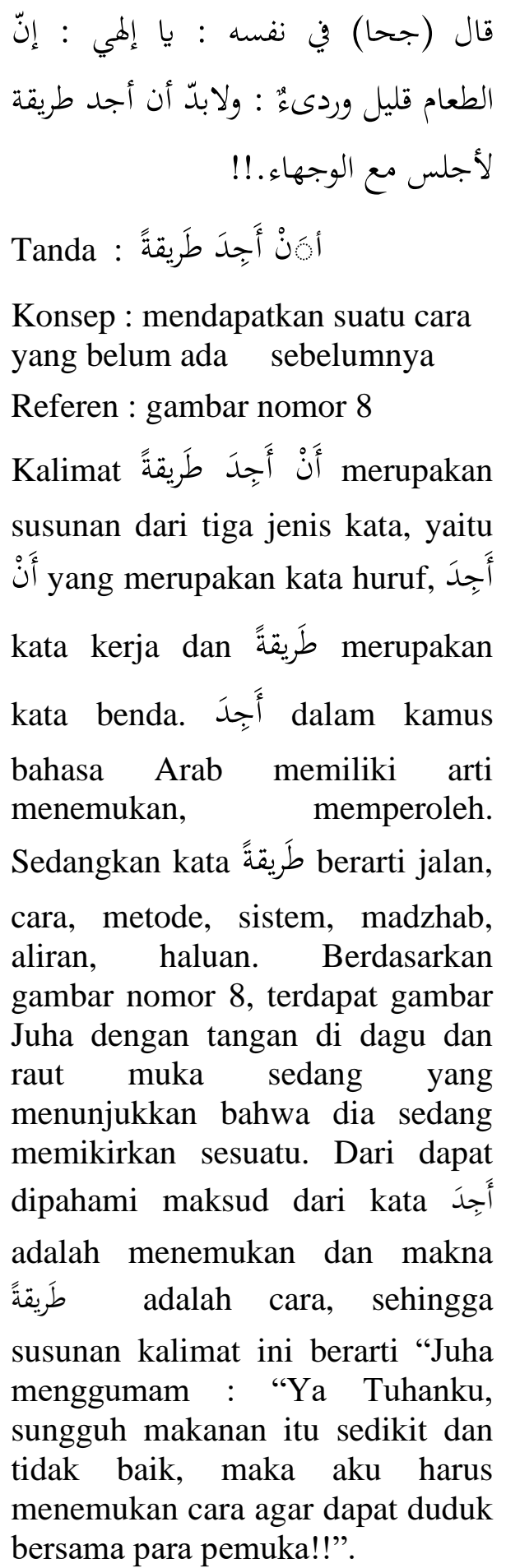 \\
\hline
\end{tabular}


ALIBBAA': Jurnal Pendidikan Bahasa Arab, 2 (1), 2021

\begin{tabular}{|c|c|}
\hline ن الوليتــ & 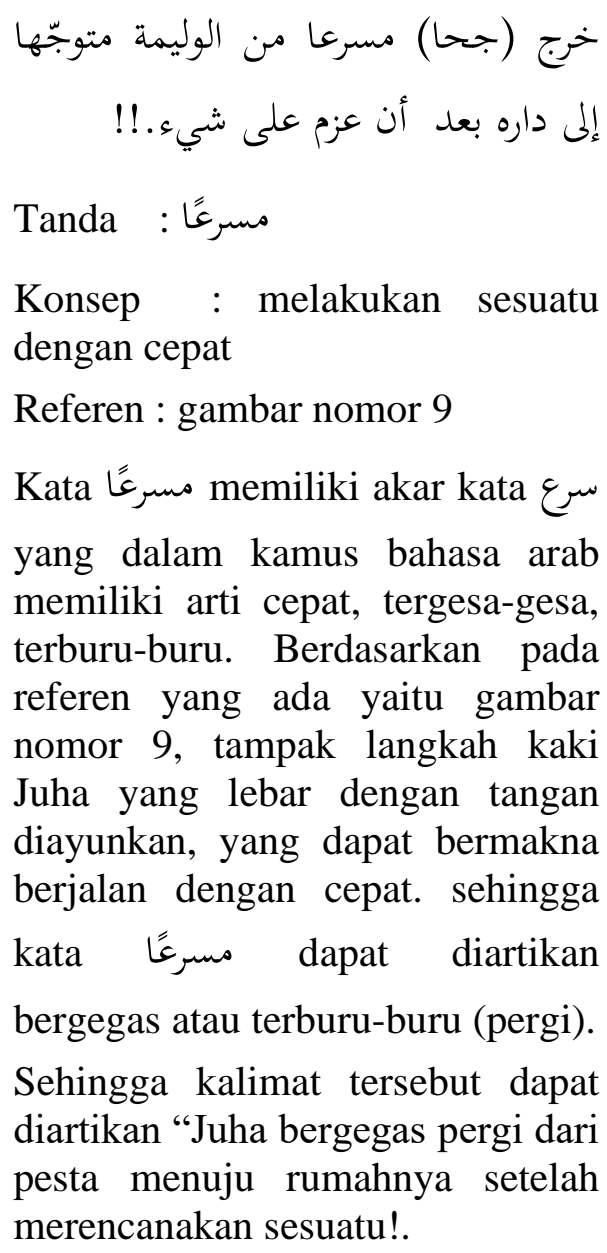 \\
\hline 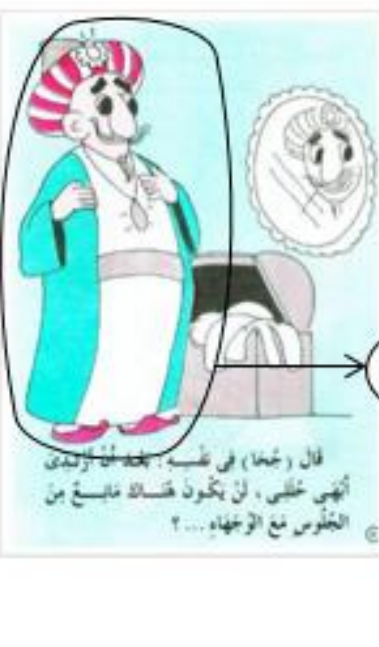 & 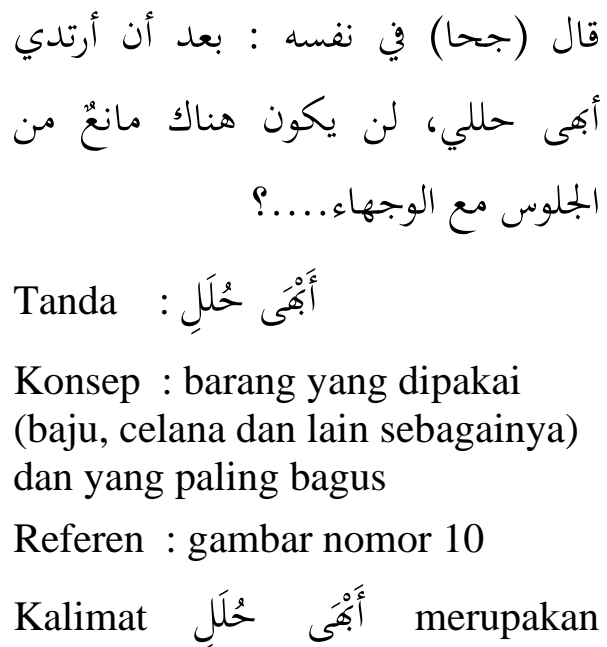 \\
\hline
\end{tabular}




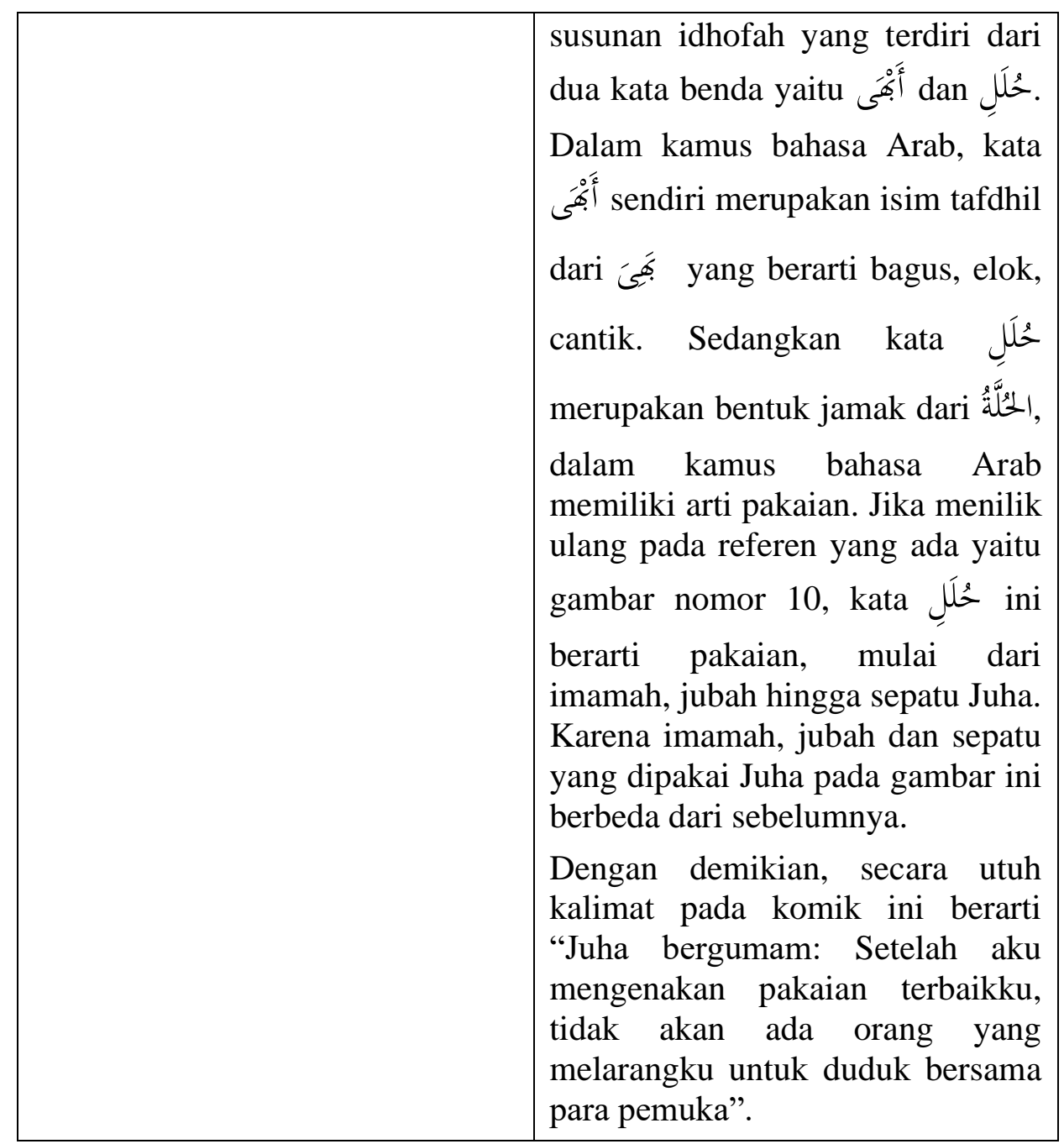




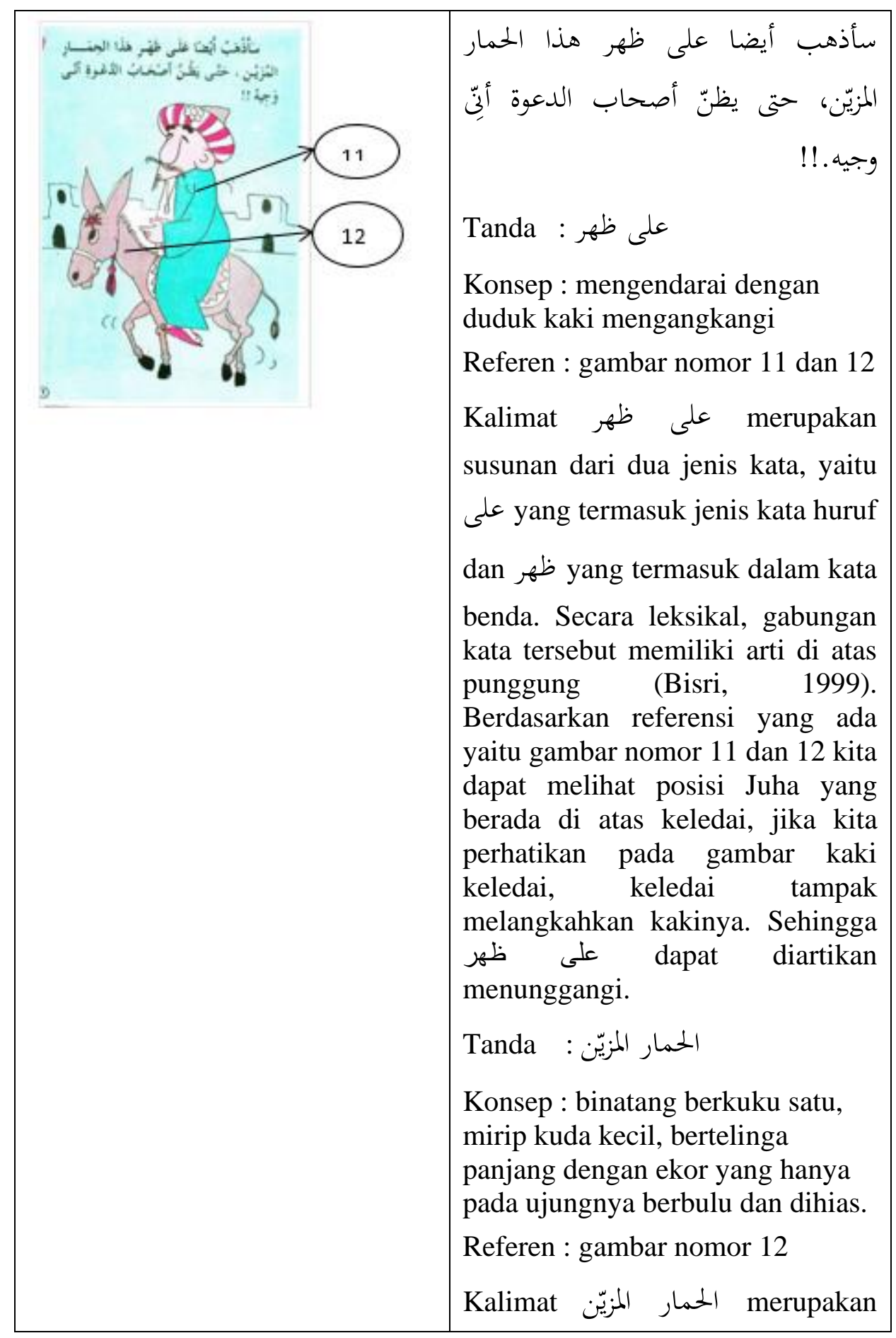


ALIBBAA': Jurnal Pendidikan Bahasa Arab, 2 (1), 2021

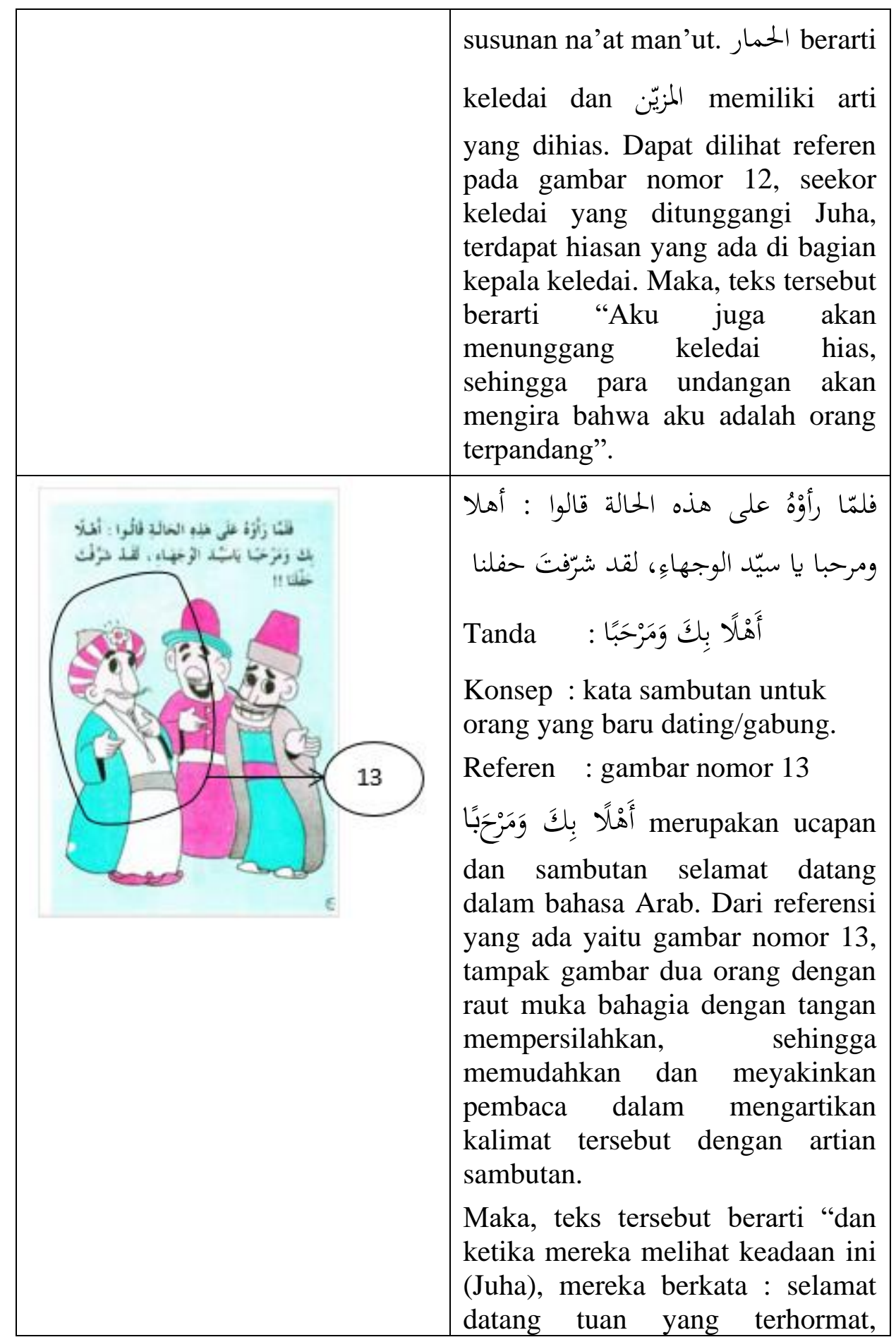


ALIBBAA': Jurnal Pendidikan Bahasa Arab, 2 (1), 2021

\begin{tabular}{|c|c|}
\hline & selamat menikmati pesta kami”. \\
\hline 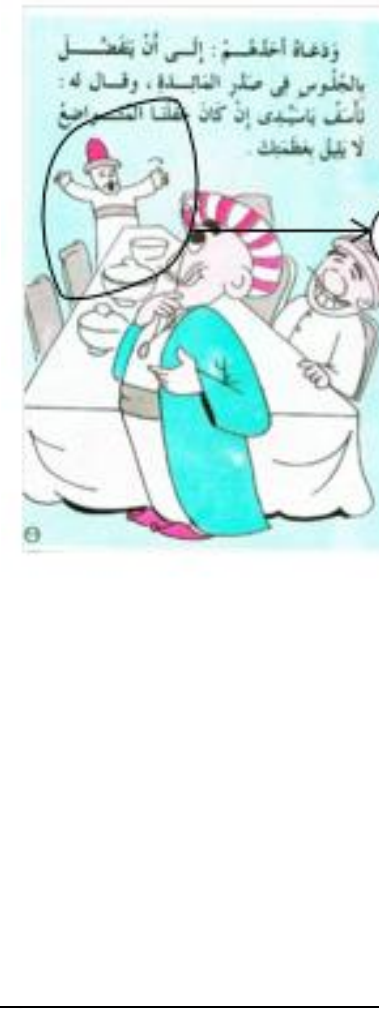 & 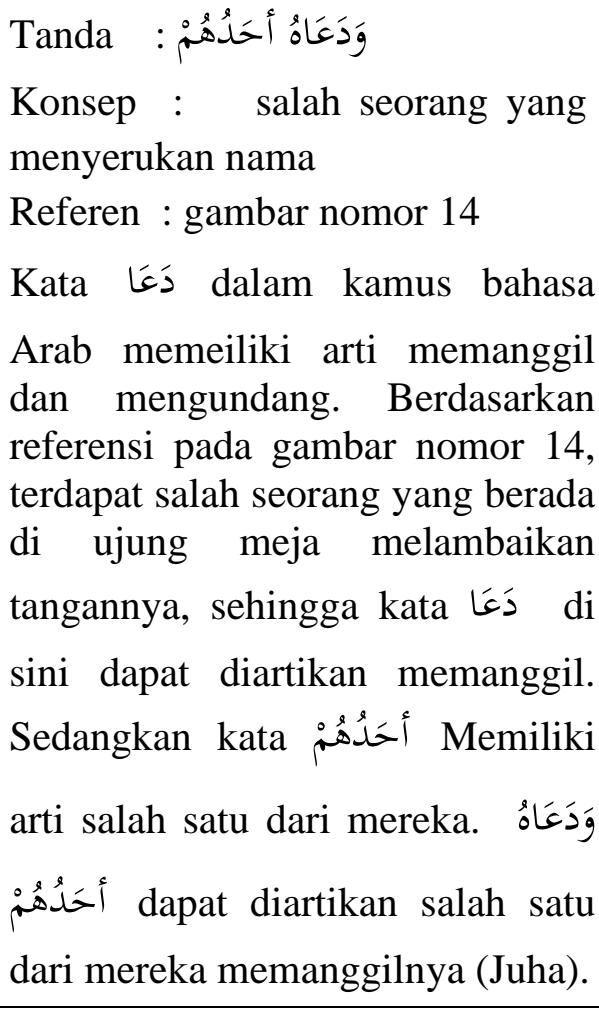 \\
\hline$\overbrace{}^{2 x}$ & 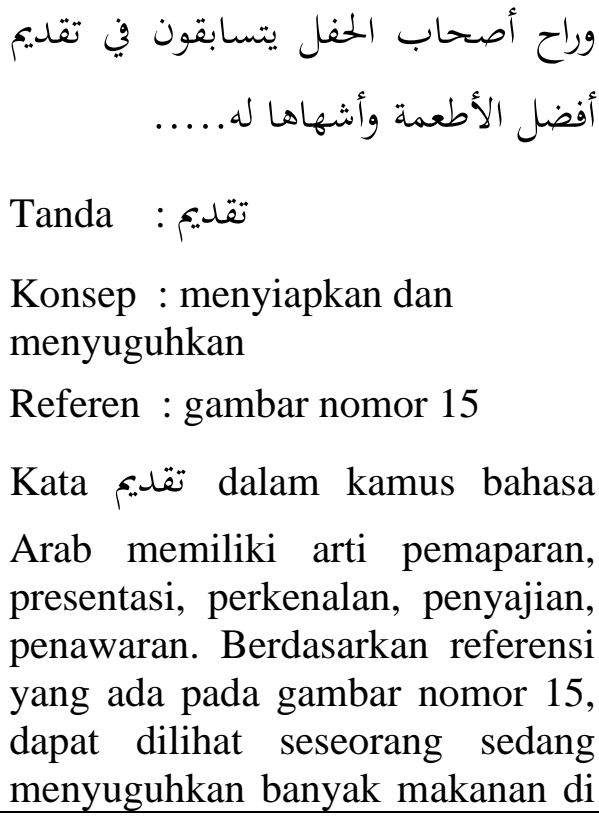 \\
\hline
\end{tabular}




\begin{tabular}{|c|c|}
\hline & $\begin{array}{l}\text { hadapan Juha, sehingga kata تقديم } \\
\text { di sini berarti penyajian. }\end{array}$ \\
\hline 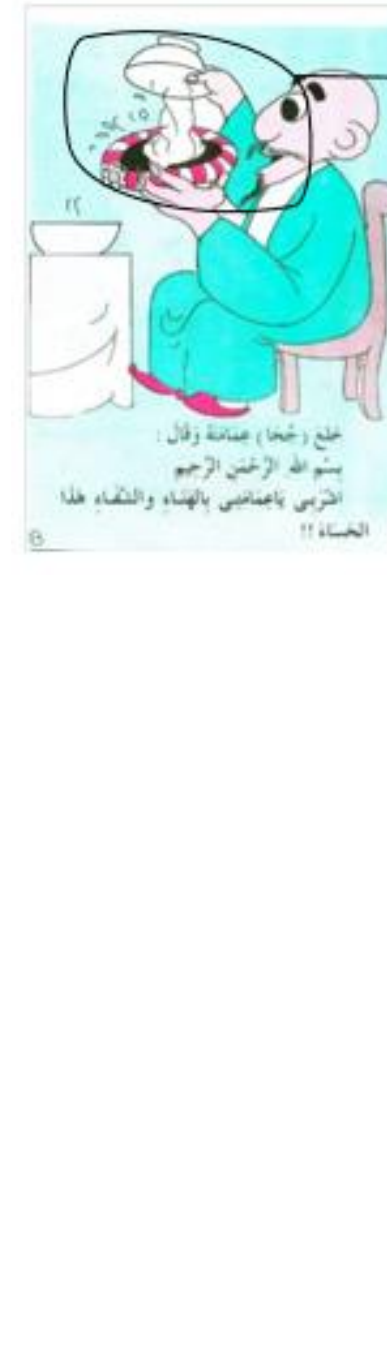 & 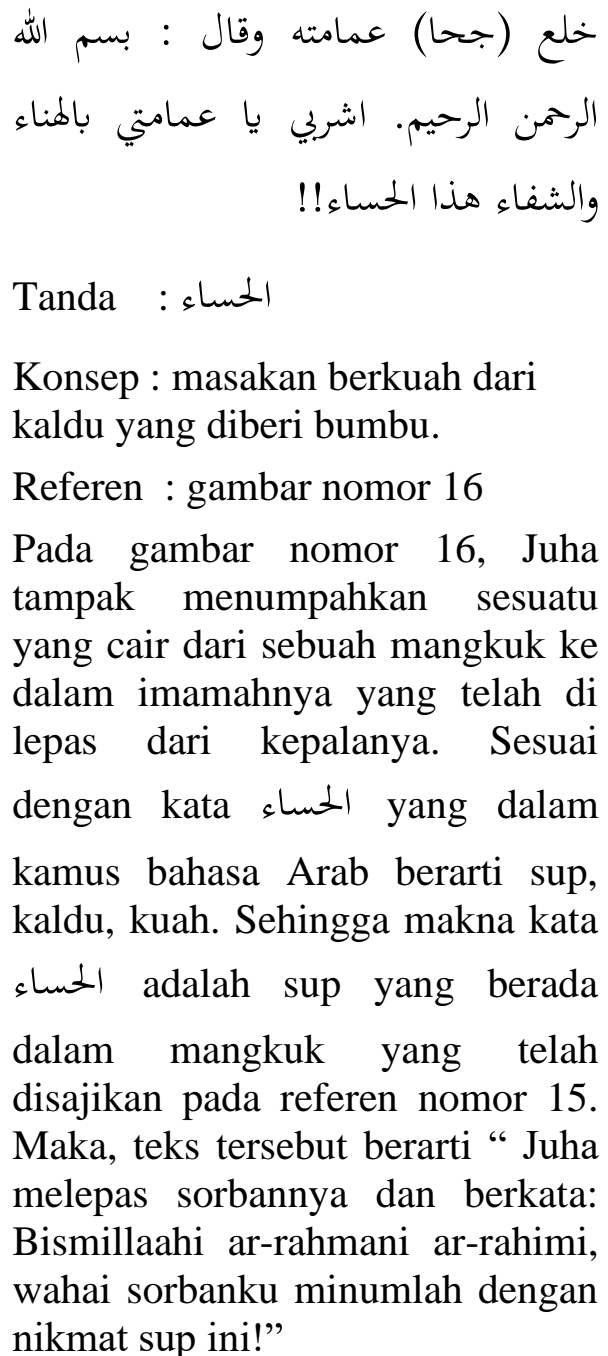 \\
\hline
\end{tabular}


ALIBBAA': Jurnal Pendidikan Bahasa Arab, 2 (1), 2021

\begin{tabular}{|c|c|}
\hline 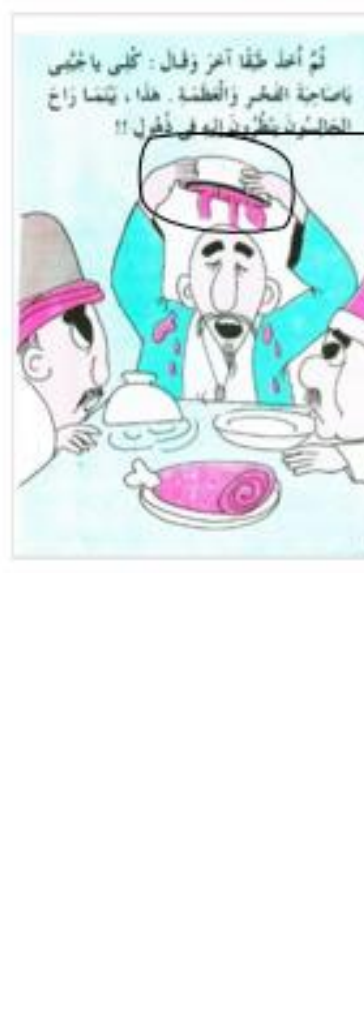 & 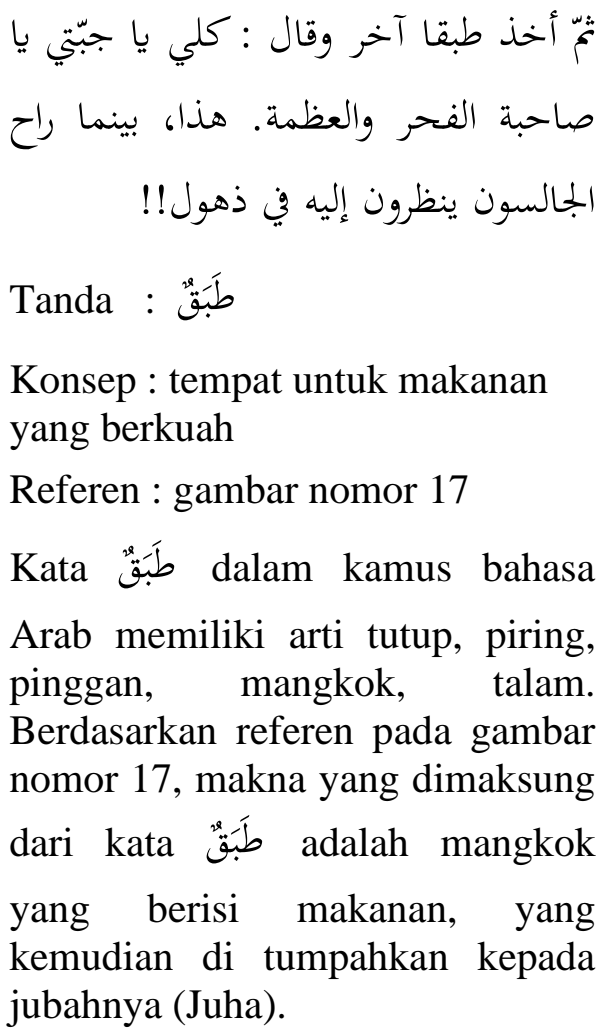 \\
\hline كا" & 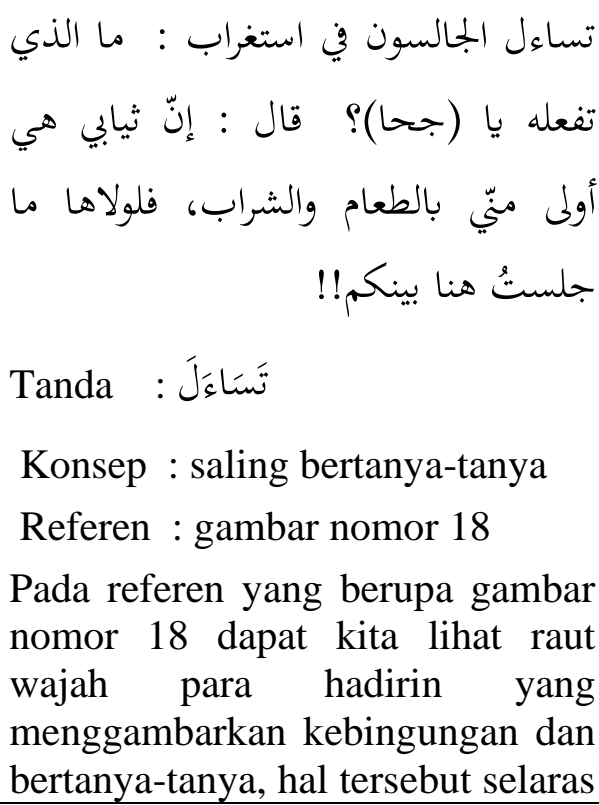 \\
\hline
\end{tabular}




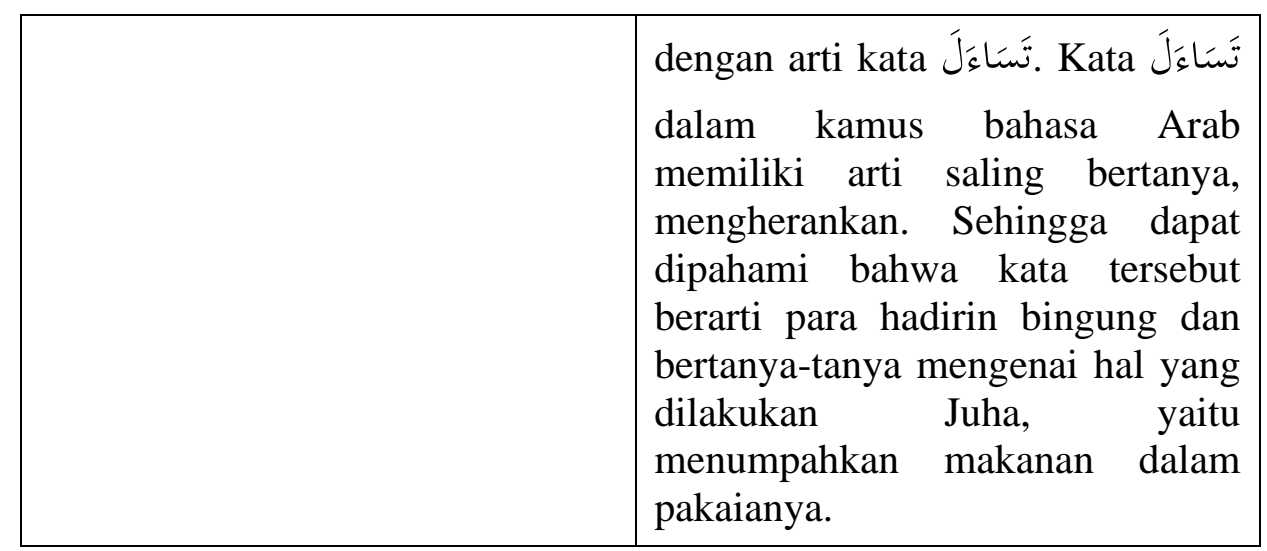

\section{Kesimpulan}

Berdasarkan hasil analisis makna referensial pada komik bahasa Arab Nawadhir Juha li al-Athfal dengan menggunakan teori Ferdinand De Saussure, yaitu melihat dari segi tanda linguistik signifian dan signifie. Terdapat 18 makna referensial. Tanda lingusitik memiliki peran yang penting dalam membantu pembaca memahami alur cerita dalam komik. Karena satu kosa kata dalam bahasa Arab terkadang tidak hanya memiliki satu arti, sehingga dengan adanya tanda linguistik sangat membantu dalam menentukan arti yang dimaksud.

Makna keseluruhan dari data yang terkumpul adalah pembahasan mengenai kisah Juha yang awalnya dipandang sebelah mata saat menghadiri suatu pesta dengan mengenakan pakaian layaknya rakyat biasa. Dia tidak diperkenankan duduk dengan para pemuka kaum. Namun setelah Juha mengganti bajunya dengan pakaian yang mewah serta menunggang keledai yang dihias, Juha dihormati dan dipersilahkan duduk dengan para pemuka kaum, dihidangkan untuknya makanan yang lezat. Di akhir cerita Juha menumpahkan semua makanan yang disuguhkan ke dalam imamah dan jubahnya yang membuat dia dihormati. Oleh sebab itu, judul dalam kisah ini adalah

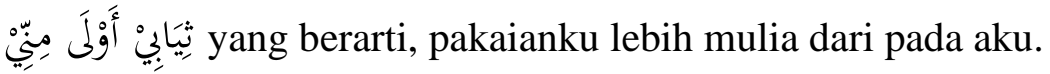




\section{DAFTAR PUSTAKA}

Allan, Keith. Natural Language Semantics. Oxford, UK; Malden, Mass: Blackwell, 2001.

Cahyani, Medita Agla. 'Penerjemahan Komik Nawadhir Juha Li AlAthfal'. Universitas Islam Negeri Syarif Hidayatullah, 2018. https://www.academia.edu/35723006/revisi_proposal_skripsi_k omik_nawadhir_juha_li_al_athaf_docx.

Cahyo, Nur. 'Makna Referensial Pada Istilah Pendidikan Dalam Kolom Wacana Pendidikan Surat Kabar Harian Solopos Edisi JanuariFebruari 2014', 2014.

Chaer, Abdul. Linguistik Umum. Jakarta: Rineka Cipta, 2007.

Creswell, John W. Research Design: Qualitative, Quantitative, and Mixed Methods Approaches. 4th ed. Thousand Oaks: SAGE Publications, 2014.

Deviyana, Ade Destry. ' 'Ilm ad-dalalah: 'Alaqatul Ma'na fi al-Lughah al-Arabiyah wa al-Lughah Al-Injiliziyah wa al-Lughah alIndunisiyah'. Al-Ta'rib: Jurnal Ilmiah Program Studi Pendidikan Bahasa Arab IAIN Palangka Raya, Vol.4, No. 1, 2016. https://doi.org/10.23971/altarib.v4i1.557.

Kurniawan, Reski, Sumiharti Sumiharti, and Firman Tara. 'Analisis Makna Referensial Pada Rubrik Pendidikan Dalam Surat Kabar Jambi Ekspres Edisi Bulan Maret 2017'. Aksara: Jurnal Ilmiah Pendidikan Bahasa Dan Sastra Indonesia, Vol.2, No. 1, 2018: 192-200.

Leech, Geoffrey N, and M. D. D Oka. Prinsip-prinsip pragmatik. Jakarta: Universitas Indonesia, 1993. 
Levinson, Stephen C. Pragmatics. Cambridge Textbooks in Linguistics. Cambridge [Cambridgeshire]; New York: Cambridge University Press, 1983.

Lyons, John. Linguistic Semantics: An Introduction. Cambridge; New York: Cambridge University Press, 1995.

—. Semantics. Cambridge; New York: Cambridge University Press, 1977.

Mahsun, Mahsun. Metode Penelitian Bahasa Tahapan Strategi, Metode, Dan Tekniknya. Jakarta: PT Raja Grafindo Persada, n.d.

McElvenny, James. 'Ogden and Richards' The Meaning of Meaning and Early Analytic Philosophy'. Language Sciences 41 (January 2014): 212-21. https://doi.org/10.1016/j.langsci.2013.10.001.

Nöth, Winfried. Handbook of Semiotics. Indiana University Press, 1995.

Priatmie, Tivany Inggar, and Atiqa Sabardila. 'Makna Referensial Pada Kritikan Di Situs Ngomikmaksa Dan Relevansinya Sebagai Bahan Ajar Di SMA'. Jurnal Penelitian Humaniora 17 (2016).

Sobur, Alex. Semiotika Komunikasi. Bandung: PT Remaja Rosdakarya, 2013.

Sudaryanto, Sudaryanto. Metode Dan Aneka Teknik Analis Bahasa. Yogyakarta: Duta Wacana University Press, 2015.

Sugiyono, Sugiyono. Metode Penelitian Pendidikan. Bandung: Alfabeta, 2015.

Sukmadinata, Nana Syaodih. Metode Penelitian Pendidikan. Bandung: PT Remaja Rosdakarya, 2009. 
ALIBBAA'? Jurnal Pendidikan Bahasa Arab, 2 (1), 2021

Sutarjo, Sutarjo. 'Istikhdam Wasilah Ar-Rusum al-Hajaliyah Fi Maharah al-Qira'ah'. النابغة Vol. 18, No. 2, 2016: 221-37.

Wiersma, William, and Stephen G. Jurs. Research Methods in Education: An Introduction., 2009. 